\title{
Induction of Interleukin-6 in Axotomized Sensory Neurons
}

\author{
P. G. Murphy, J. Grondin, M. Altares, and P. M. Richardson \\ Division of Neurosurgery, McGill University and Montreal General Hospital, Montreal, Quebec, Canada H3G 1A4
}

RNA from rat dorsal root ganglia was analyzed in search of potentially beneficial cytokines that are induced in dorsal root ganglia by nerve injury. By reverse transcription, the PCR, and Southern blotting, interleukin-6 mRNA was detected during development but not in normal adult dorsal root ganglia, reappeared within $1 \mathrm{~d}$ of sciatic nerve transection, was maximally increased after 2 and $4 \mathrm{~d}$, and decreased below the threshold of detection within 1 week. By RNase protection assay, interleukin- 6 mRNA was consistently present in RNA from dorsal root ganglia removed from rats $4 \mathrm{~d}$ following transection but not in control dorsal root ganglia. Interleukin-6 bioactivity was also present in dorsal root ganglia following nerve injury. By in situ hybridization, interleukin- 6 mRNA was localized within large and medium-sized axotomized neurons. In summary, some sensory neurons respond to axotomy with a brisk transient increase in synthesis of interleukin-6.

Injury to the sciatic nerve also induced mRNAs for interleukin-1 $\beta$ and tumor necrosis factor- $\alpha$ in dorsal root ganglia. The inductions of interleukin-1 $\beta$ and tumor necrosis factor- $\alpha$ mRNAs were later and more sustained than that of interleukin-6 mRNA. The cellular sources of these two cytokines have not been defined.

[Key words: interleukin-6, axotomy, tumor necrosis factor, interleukin-1, neuronal gene expression, sensory neurons]

IL-6 is a pleiotrophic cytokine that stimulates the acute phase response from hepatocytes (Gauldie et al., 1987), the differentiation of B lymphocytes (Lee, 1992; Kopf et al., 1994), the synthesis of metalloproteinase inhibitors by fibroblasts (Lotz and Guerne, 1991), bone remodeling by osteoblasts (Poli et al., 1994), and protein breakdown in muscle (Goodman, 1994). Based on similarity in tertiary structure and sharing of receptor subunits, IL-6 has been classified as a member of the cytokine family which includes CNTF (ciliary neurotrophic factor), LIF (leukemia inhibitory factor), IL-11, and oncostatin M (Bazan, 1991; Ip et al., 1992; Patterson, 1992; Davis and Yancopoulos, 1993; Stahl et al., 1994). Like other neuropoietic cytokines, IL-6 has putative functions in the nervous system as well as its classical actions in the immune system and liver. In vitro, IL-6 is trophic for PC12 pheochromocytoma cells (Satoh et al., 1988)

\footnotetext{
Received Dec. 1, 1994; revised Feb. 17, 1995; accepted Feb. 23, 1995.

This work was supported by a grant to P.M.R. from NIH and a fellowship to P.G.M. from the Rick Hansen Foundation (Canada). We thank Dr. J. Gauldie for the antibody to interleukin- 6 .

Correspondence should be addressed to P. M. Richardson, Division of Neurosurgery, Montreal General Hospital, 1650 Cedar Avenue, Montreal, Canada $\mathrm{H} 3 \mathrm{G} 1 \mathrm{~A} 4$.

Copyright $(1995$ Society for Neuroscience $0270-6474 / 95 / 155130-09 \$ 05.00 / 0$
}

and some cerebral neurons (Hama et al., 1991; Yamada and Hataraka, 1994) and in transgenic mice, overexpression of IL-6 in astrocytes causes neurological dysfunction and neuronal and glial abnormalities (Campbell et al., 1993).

Cells of many types can synthesize IL- 6 usually at low basal level with local induction in inflamed or traumatized tissue. In the CNS, astrocytes and microglial cells are recognized sources of IL- 6 and expression of the IL- 6 gene is increased by injury (Woodroofe et al., 1991; Van et al., 1992; Kiefer et al., 1993; Hariri et al., 1994; Shohami et al., 1994). II,-6 mRNA has been described within hippocampal and cerebellar neurons of the adult mammalian brain (Schöbitz et al., 1993). Also, neurons have been found to synthesize a several other cytokines, growth factors, and neurotrophic factors. mRNAs for NGF, brain-derived neurotrophic factor (BDNF), acidic fibroblast growth factor (aFGF), platelet-derived growth factor (PDGF), glial growth factor (GGF), and IL-1 all have been found in neurons. (Ernfors et al., 1990; Bandtlow et al., 1991; Elde et al., 1991; Sasahara et al., 1991; Yeh et al., 1991; Marchionni et al., 1993; Shah et al., 1994).

The presence of macrophages in dorsal root ganglia is beneficial to the regeneration of dorsal root axons (Lu and Richardson, 1991) and macrophages accumulate in appropriate dorsal root ganglia after nerve injury (Lu and Richardson, 1993). Interleukin-6 (IL-6), interleukin-1 $\beta$ (IL-1 $\beta$ ), and tumour necrosis factor- $\alpha(\mathrm{TNF}-\alpha)$ are three cytokines that are strongly associated with macrophages (Johnston, 1988; Northemann et al., 1989). Accordingly, mRNAs for these three cytokines were analyzed in lumbar dorsal root ganglia associated with normal and cut sciatic nerves. Anticipating the presence of cytokine mRNAs in macrophages, we were surprised to find interleukin-6 mRNA in axotomized and embryonic sensory neurons.

\section{Materials and Methods}

Surgery. Fifty-seven adult female Sprague-Dawley rats weighing approximately $200 \mathrm{gm}$ were anesthetized wilh pentobarbital $(50 \mathrm{mg} / \mathrm{kg}$, intraperitoneally). Through a midline incision, the right sciatic nerve was transected at its origin at the L4 and L5 level, while the left side was uninjured. Ipsilateral and contralateral L4 and L5 (fourth and fifth lumbar) DRG were removed from rats anesthetized $0,1,2,4,8$, and $16 \mathrm{~d}$ after transection. DRG were also removed from embryonic (E15), neonatal (P1 and P2), and five unoperated adult rats. Following removal, DRG were either placed immediately in liquid nitrogen for RT-PCR or frozen at $-60^{\circ} \mathrm{C}$ in 2-methyl butane for in situ hybridization.

$R T-P C R$. RNA was isolated from rat adult, embryonic, and neonatal DRG by a modification of the procedure of Chomczynski and Sacchi (1987). Following acid phenol, phenol-chloroform, and chloroform ex tractions, plus ethanol precipitation, the RNA was resuspended in water, digested with $5 \mathrm{U} / \mu \mathrm{g}$ RNA of RNase free DNase (Promega Corp.) at $37^{\circ} \mathrm{C}$ for $15 \mathrm{~min}$, reextracted wilh phenol-chloroform, and precipitated. RNA isolated from rat spleen tissue served as a positive control. The RNA was then quantified with spectrophotometry and denaturing agarose electrophoresis (Sambrook et al., 1989). Equal amounts $(5 \mu \mathrm{g})$ of RNA from ipsilateral and contralateral DRG were reverse transcribed 
with random hexanucleotide primers $(1 \mu \mathrm{g}$, Pharmacia LKB Biotechnology AB), $500 \mu \mathrm{M}$ dNTPs (Pharmacia), $20 \mathrm{U}$ of RNasin (Promega), $200 \mu \mathrm{M}$ dithiothreitol (DTT) (GIBCO-Bethesda Research Labs Life Technologies Inc.), and $10 \mathrm{U}$ of MMLV (Moloney muríne leukemia virus) reverse transcriptase (GIBCO-BRL) for $2 \mathrm{hr}$ at $37^{\circ} \mathrm{C}$. Following this incubation, the samples were heated for $5 \mathrm{~min}$ at $95^{\circ} \mathrm{C}$, diluted, and aliquoted.

The PCR was performed with a thermal cycler (MJ Research Inc.) and reaction mixture containing cDNA transcribed from 50 ng RNA (typically), $100 \mu \mathrm{M}$ dNTPs, $1 \mu \mathrm{M}$ of each primer, $1.5 \mathrm{mM} \mathrm{MgCl}$, and $2.5 \mathrm{U}$ Taq polymerase (GIBCO-Bethesda Research Labs). Relative quantities of starting material and efficiency of RT were controlled by PCR (20 cycles) and Southern blotting with specific primers for rat glyceraldehyde 3-phosphate dehydrogenase (GAPDH). The primers used were TGAAGGTCGGTGTCAACGGATTTGGC, CATGTAGGCCATGAGGTCCACCAC, corresponding to nucleotides 35-60 (sense) and 994-1017 (antisense) and the hybridizing oligonucleotide was CTGGCATGGCCTTCCGTGTTCCT $\triangle$ CCCCC $\triangle \wedge$ TGTATCCGT, nucleotides 710-750 (Tso et al., 1985). Approximately equal amounts of cDNA were subjected to PCR $\left(20\right.$ cycles: $1 \mathrm{~min}$ at $95^{\circ} \mathrm{C}, 1 \mathrm{~min}$ at $55^{\circ} \mathrm{C}$, 2 min at $72^{\circ} \mathrm{C}$ ) with specific primers within translated sequences of (1) rat IL-6, TTCCCTACTTCACAAGTC and CTAGGTTTGCCGAGTAGA corresponding to nucleotides 134-154 (sense) and 684700 (antisense) (Northemann et al., 1989); (2) rat IL-1 $\beta$, ATAGCAGCTTTCGACAGTGAG, GTCAACTATGTCCCGACCATT corresponding to nucleotides 33-51 (sense) and 759-780, (antisense) (Nishida et al., 1988); and (3) rat TNF- $\alpha$, AAGTTCCCAAATGGGCTC, TCACAGAGCAATGACTCCAAAG corresponding to nucleotides 1492-1509 (sense) and 2424-2445 (antisense) of the rat genomic sequence (Shirai et al., 1989). Following PCR, the samples were electrophoresized through a $1.5 \%$ agarose gel and transferred to Nytran + membrane (Schleicher and Schuell). The membranes were prehybridized for $2-6 \mathrm{hr}$ in a solution containing $20 \mathrm{~mm}$ sodium phosphate, $6 \times$ SSC, $100 \mu \mathrm{g} / \mathrm{ml}$ salmon sperm DNA, $10 \%$ dextran sulfate, $5 \times$ Denhardt's solution, and $0.5 \%$ SDS at $42^{\circ} \mathrm{C}$ (Sambrook et al., 1989). Internal oligonucleotides for IL-6, TCACAGAAGGAGTGGCTAAGGACCAAGACCATCCAACTCATCTTGAAA, nucleotides 602-649 (Northemann et al., 1989); IL-1 $\beta$ TTCTATCTTGTTGAAGACAAACCGTTTTTCCATCTTCTTCTTTGGGTA, nucleotides 615-663 (Nishida et al., 1988); and TNF- $\alpha$ GATCATCTTCTCAAAACTCGAGTGACAAGCCCGTAGCCCACGTCGTAG, nucleotides 1695-1742 (Shirai et al., 1989) were labeled with ${ }^{32}$ P-dCTP (Amersham Corp.) to a specific activity $>10^{9} \mathrm{cpm} / \mu \mathrm{g}$ by random primer extension (Sambrook et al., 1989), separated from unincorporated nucleotides by gel filtration (Stratagene Cloning Systems), and added to the hybridization buffer at a concentration of $10 \mathrm{ng} / \mathrm{ml}$. Membranes were washed according to the manufacturer's specifications and exposed $24-48 \mathrm{hr}$ for radioautography. Specificity of the IL-6 PCR product detected in the DRG was also confirmed with subcloning into pGEM-7Zf(-) (Promega) and dideoxy DNA sequencing (Sequenase, Amersham) (Sambrook et al., 1989).

RNase protection. For RNase protection assays (Seniuk et al., 1992), a 597 bp IL- 6 cDNA product was obtained by RT-PCR from rat spleen RNA, subcloned into the BamHl site of the pGEM-7Zf(-) plasmid vector, and confirmed in identity by dideoxy sequencing (Sambrook et al., 1989). IL-6 cDNA was linearized with HindIII and $250 \mathrm{ng}$ of plasmid DNA were transcribed into an antisense RNA probe with SP6 RNA polymerase (Stratagene), $100 \mu \mathrm{Ci} \alpha^{32}$ P-CTP (Amersham) and $400 \mu \mathrm{m}$ NTPs producing a $612 \mathrm{bp}$ antisense riboprobe. After incubation of the reaction mixture at $40^{\circ} \mathrm{C}$ for $2 \mathrm{hr}$, plasmid DNA was digested with DNase, extracted with phenol-chloroform, and purified by gel filtration (Stratagene). To control for RNA integrity and quantity (Jakubowski and Roberts, 1992), a cyclophilin RNA probe of lower specific activity, 142 base pairs in length, was prepared from rat cyclophilin cDNA (kindly donated by G. Kuchel, Montreal General Hospital). RNA from DRG $(2.5-30 \mu \mathrm{g})$ was incubated with $50,000 \mathrm{cpm}$ of both IL-6 and cyclophilin antisense riboprobes overnight at $50^{\circ} \mathrm{C}$. Following digestion with RNase A $(1.0 \mu \mathrm{g} / \mathrm{ml})$ and RNase $\mathrm{T} 1(100 \mathrm{U} / \mathrm{ml})$, the protected fragments were separated by electrophoresis through a $4 \%$ urea-polyacrylamide gel and visualized by radioautography. DNA markers (GIBCOBethesda Research Labs) were labeled with T4 DNA polymerase (GIBCO-Bethesda Research Labs) and ${ }^{35}$ S-dC'TP (Sambrook et al., 1989). The expected protected fragment sizes for the IL-6 and cyclophilin mRNAs are 597 and $117 \mathrm{bp}$, respectively.

In situ hybridization. For in situ hybridization, DRG were removed from anesthetized rats, frozen immediately at $-60^{\circ} \mathrm{C}$ in 2 methyl bu- tane, embedded in Tissue-Tek, (Miles Laboratory), and stored at $-70^{\circ} \mathrm{C}$. Contralateral and ipsilateral DRG were embedded in the same block. Frozen sections, $10 \mu \mathrm{m}$ thick, were mounted on Probe-on slides and hybridized $16-18 \mathrm{hr}$ at $42^{\circ} \mathrm{C}$. with a solution containing $500,000 \mathrm{cpm}$ of ${ }^{35}$ S-labeled IL-6 oligonucleotides, $50 \%$ formamide, $4 \times$ SSC, dextran sulfate $(100 \mathrm{mg} / \mathrm{ml})$, sarcosyl $(1 \%) 500 \mu \mathrm{g} / \mathrm{ml}$ salmon sperm DNA, and $200 \mathrm{~mm}$ DTT. Oligonucleotides were GGTGGTATCCTCTGTGAAGTCTCCTCTCCGGACTTGTGAAGTAGGGAA, TTTCAAGATGAGTTGGATGGTCTTGGTCCTTAGCCACTCCTTCTGTAG antisense to nucleotides 137-154 and 602-649 within the translated portion of the IL- 6 mRNA (Northemann et al., 1989) and labeled by the terminal transferase reaction (Sambrook et al., 1989). Following hybridization, the slides were washed four times in $1 \times \mathrm{SSC}$ at $55^{\circ} \mathrm{C}$ for $15 \mathrm{~min}$. The tissues were fixed briefly in $65 \%$ and $95 \%$ ethanol, dried, dipped in emulsion (NTB2 Kodak), exposed for 4-6 weeks after which they were developed, fixed, and then stained with $0.002 \%$ toluidine blue.

PCR-enhanced in situ hybridization for the IL-6 mRNA was performed with the primers used for PCR and a thermal cycler equipped with a slide griddle. Cryostat sections, $10 \mu \mathrm{m}$ thick, of unfixed tissue were digested with DNase (1 U/ $\mu$ l final concentration) (Promega) overnight at $37^{\circ} \mathrm{C}$. After rinsing, reverse transcription was performed with $4 \mathrm{~mm}$ dNTPs, $1 \mathrm{U} / \mu \mathrm{l}$ RNAsin (Promega), $0.5 \mathrm{U} / \mu \mathrm{l}$ MMLV RT, and 1 $\mu \mathrm{M}$ of $3^{\prime}$ primer at $37^{\circ} \mathrm{C}$ for $1 \mathrm{hr}$. Following RT, slides were heated at $95^{\circ} \mathrm{C}$ for $5 \mathrm{~min}$ and the PCR reaction was done (30 cycles with 1.25 $\mu \mathrm{M}$ of both primers, $10 \mu \mathrm{M}$ dNTPs, $1.5 \mathrm{mM} \mathrm{MgCl}_{2}$, and $2.5 \mathrm{U}$ of Taq polymerase). Following PCR, in situ hybridization with the internal IL-6 oligonucleotides was performed as described in the preceding paragraph.

Neuronal labeling in situ hybridization was quantified with a computerized image analysis system (Verge et al., 1990) for pairs of sections on the same slide. Only cells with visible nucleolus were quantified. Labeling index refers to the ratio of grain density over neurons to grain density of non-neuronal portions of the DRG.

$I L-6$ bioactivity. IL- 6 bioactivity was assayed with the IL- 6 dependent mouse B9 cell line (B lymphocyte hybridoma, Aarden et al., 1987) kindly provided by Dr. J. Gauldie, McMaster University, Canada. Under sterile conditions, ipsilateral and contralateral DRG were removed from rats 3 or $4 \mathrm{~d}$ following sciatic nerve transection and frozen at $-20^{\circ} \mathrm{C}$. Cells within the DRG were lysed by repeated freeze-thaw cycles. B9 cells, 2500 per microwell in $200 \mu \mathrm{l}$ RPMl culture medium and $5 \%$ fetal calf serum, were coincubated with either DRG or exogenous murine IL-6 for $72 \mathrm{hr}$. DRG were then removed and B9 cells were counted in representative high-power fields. To confirm specificity of the bioactivity, additional assays were performed in the presence of rabbit polyclonal antibody to II -6 (kindly supplied by Dr. J. Gauldie) at a final dilution of $1: 250$.

\section{Results}

$R T-P C R$

Analysis of IL- 6 mRNA by RT-PCR and Southern blotting revealed a PCR product of approximately $600 \mathrm{bp}$ derived from the RNA isolated from ipsilateral L4 and L5 DRG following sciatic nerve transection (Fig. 1). In 10 assays under the same conditions from two RNA preparations of two groups of contralateral DRG and two groups of unoperated rats, no IL-6 PCR product was detected (Fig. 1). IL-6 mRNA was detectable in the ipsilateral DRG as early as $1 \mathrm{~d}$ following transection, peaked in concentration at 2 and $4 \mathrm{~d}$, and was undetectable at $8 \mathrm{~d}$ or 2 weeks (Fig. 1). Additional experiments indicate that IL-6 mRNA is also undetectable 1 month following injury.

The failure to detect IL- 6 mRNA in normal DRG is not duc to degradation of RNA or failure of reverse transcription because GAPDH product could consistently be obtained with all four batches of cDNA. The IL-6 PCR product derived from DRG after injury is not the result of amplification of genomic DNA since PCR without reverse transcription did not yield any detectable signal with Southern blotting. Also, the primers utilized were designed to span exon-intron boundaries, therefore yielding different sized products for cDNA and genomic DNA. The 

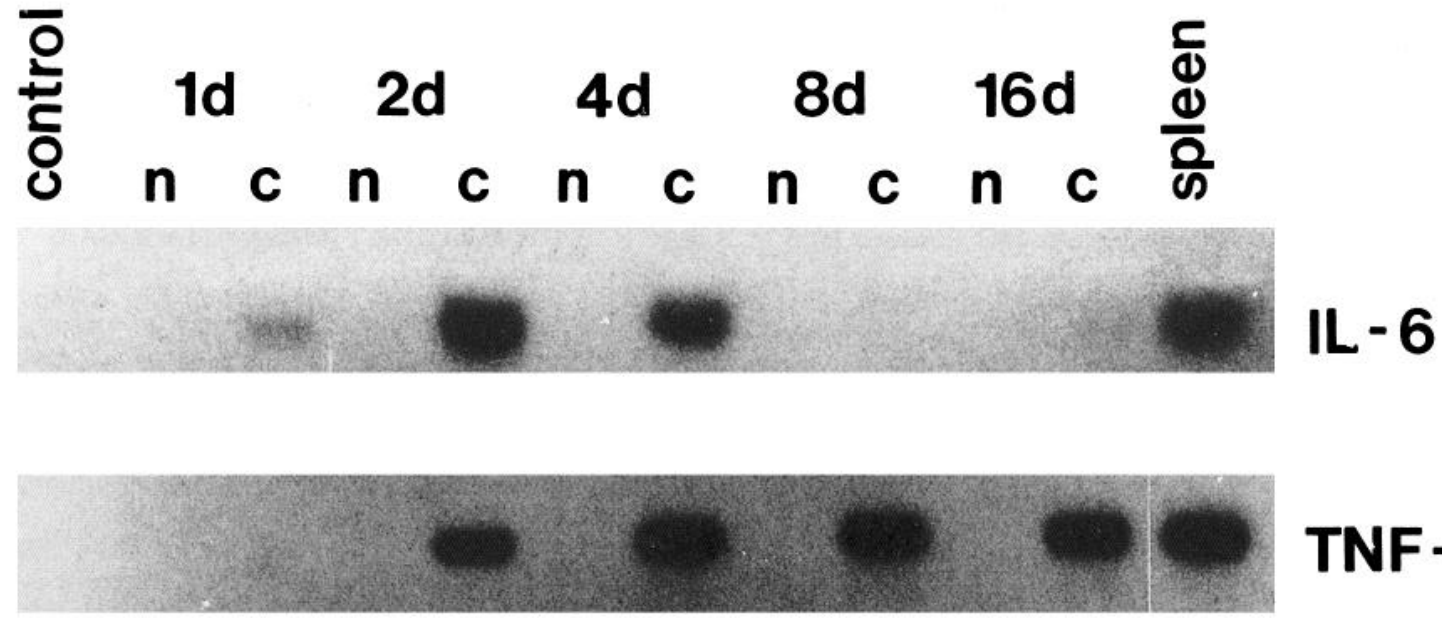

\section{TNF- $\alpha$}

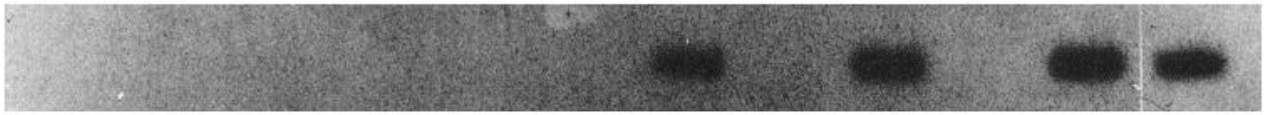

IL-1B

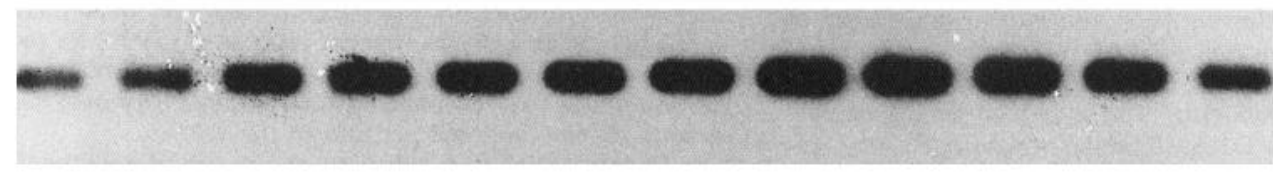

GAPDH

Figure 1. Southern blots of RT-PCR samples analyzing the mRNA (50 ng) from L4 and L5 DRG associated with cut (c) or normal ( $n$ ) sciatic nerves. Upper panels, Southern blot of RT-PCR products for IL-6 (20 cycles), TNF- $\alpha$ ( 22 cycles), and IL-1 $\beta$ ( 22 cycles) demonstrating a distinct time course of induction for each mRNA. Lower panel, Southern blot for GAPDH RT-PCR product demonstrating approximately equal amounts of product in all cDNA samples.

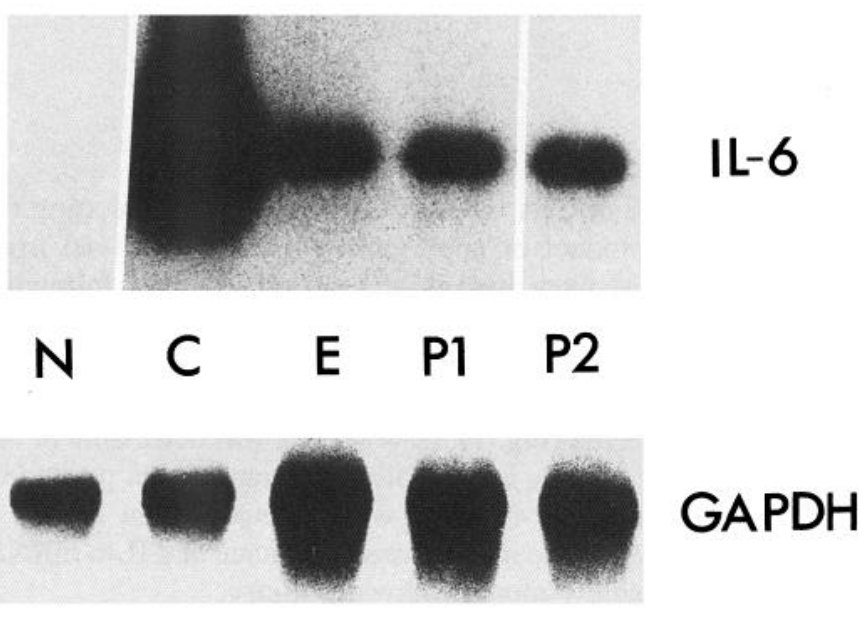

Figure 2. Upper panel, Southern blot for IL-6 RT-PCR product (20 cycles) analyzing RNA (50 ng) from contralateral $(n)$ and ipsilateral L4 and L5 DRG $2 \mathrm{~d}$ after nerve injury and from embryonic (e) (E15, 100 $\mathrm{ng})$ and neonatal ( $P I$ and $P 2,100 \mathrm{ng})$ DRG. A band at approximately $600 \mathrm{bp}$ is seen in ipsilateral, embryonic, and neonatal DRG but not in contralateral DRG. Lower panel, Southern blot for the GAPDH PCR product $(20$ cycles) demonstrating more starting cDNA in the developing DRG than adult DRG. Note that the amount of IL-6 PCR product in embryonic and neonatal DRG is much less than that in ipsilateral DRG even with twice as much starting sample.
IL-6 PCR product was also identified by sequencing of approximately 300 nucleotides (Northemann et al., 1989).

IL-6 mRNA was also present in RNA isolated from DRG of embryonic (E15) and neonatal (P1 and P2) rats. By Southern blotting, the RT-PCR product from $100 \mathrm{ng}$ of RNA isolated from embryonic or neonatal DRG was less abundant than the RT-PCR product from $50 \mathrm{ng}$ RNA from adult DRG after nerve injury (Fig. 2).

Axotomy also resulted in an induction of the mRNAs for IL$1 \beta$ and TNF- $\alpha$ in the ipsilateral DRG, although the time course of induction for each mRNA was distinct. By RT-PCR (22 cycles from 50 ng RNA) and Southern blotting, mRNA for TNF- $\alpha$ was consistently detectable in DRG 2-16 d following transection (Fig. 1). With an increase in cycle number (30 cycles) and in the amount of starting cDNA (100 ng), TNF- $\alpha$ mRNA could be detected in DRG $1 \mathrm{~d}$ after injury. The PCR product was approximately $660 \mathrm{bp}$ in length and comigrated with a PCR product from spleen (Fig. 1). A 750 bp PCR product for IL-1 $\beta$ mRNA was first detected $4 \mathrm{~d}$ after nerve transection and remained detectable for at least $16 \mathrm{~d}$ (Fig. 1). This product also comigrated with a PCR product from spleen RNA. Occasionally, IL-1 $\beta$ mRNA was detected in DRG contralateral to the side of injury but not in DRG of control rats (data not shown). To detect IL-1 $\beta$ and TNF- $\alpha$ mRNAs in DRG after nerve injury, higher 

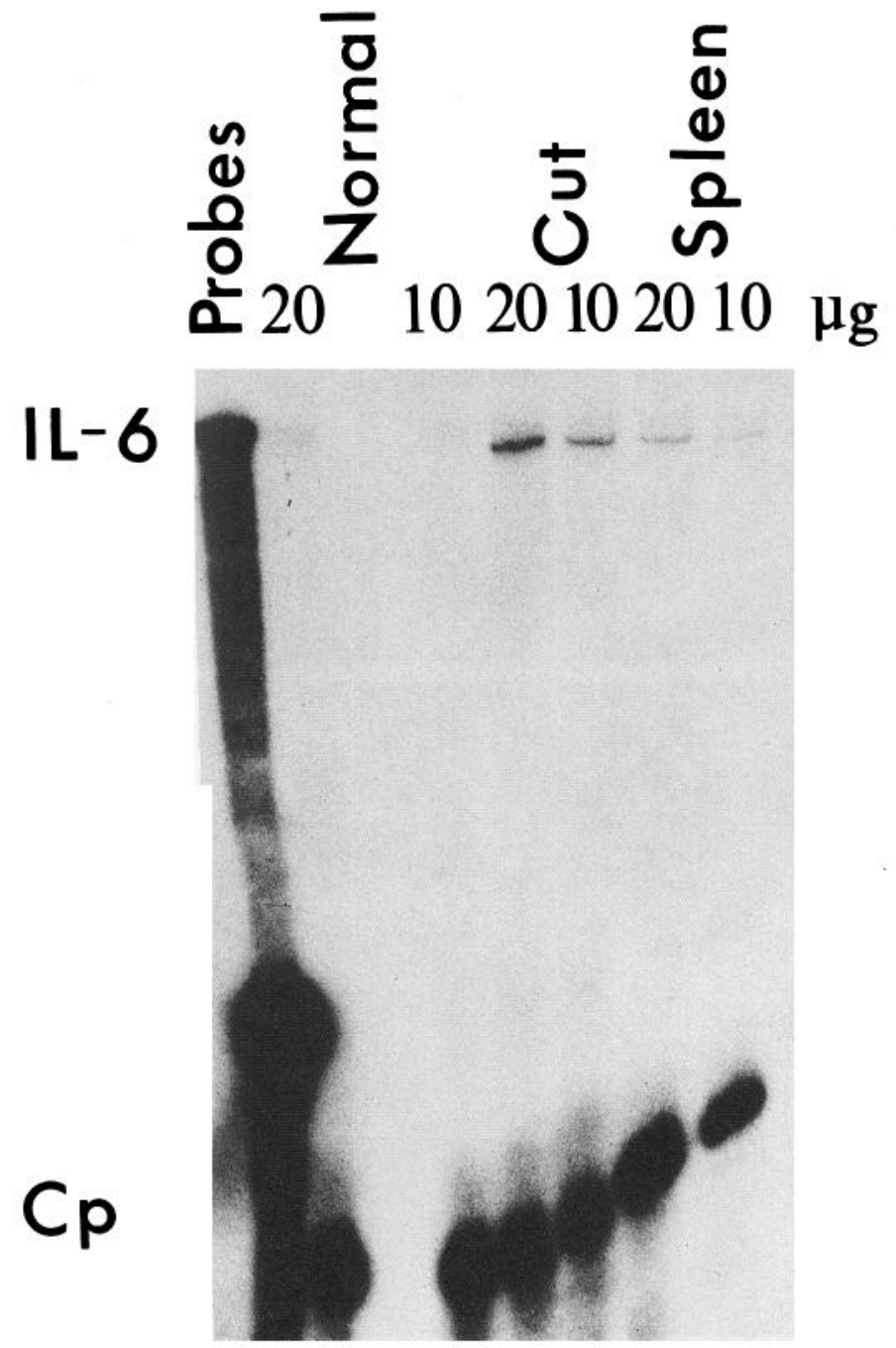

Figure 3. RNase protection assay of RNA from contralateral and ipsilateral DRG $2 \mathrm{~d}$ following transection of the right sciatic nerve hybridized simultaneously with a 612 bp IL-6 and a 142 bp cyclophilin riboprobe and demonstrating a protected fragment for IL-6 of approximately the expected size (597 bp) in the RNA from right (Cut) L4 and L5 DRG but no detectable protection in RNA from left (Normal) DRG. In addition, this protected fragment comigrates with a fragment from spleen tissue. Results of probing for cyclophilin mRNA $(C p)$ indicate a protected band of approximately the expected size $(117 \mathrm{bp})$ and demonstrates that approximately equal amounts of RNA are present in the contralateral and ipsilateral samples.

cycle numbers (22) were required than for IL-6 mRNA (20 cycles).

\section{RNase protection assays}

Induction of IL-6 mRNA in DRG after nerve injury was confirmed by RNase protection assays. A protected fragment of approximately $597 \mathrm{bp}$ was detected with 20 and $10 \mu \mathrm{g}$ of RNA isolated from the ipsilateral DRG but was not detected with the same amount of RNA isolated from the contralateral DRG (Fig. 3 ). The protected fragment comigrated with a fragment from spleen (Fig. 3). Sample differences are not due to degradation of RNA or unequal amounts of RNA since the protected fragments for cyclophilin mRNA (117 bp) in both samples are approximately equal in intensity (Fig. 3). In other experiments, an IL-6 protected fragment was detectable with as little as $2.5 \mu \mathrm{g}$ of RNA from ipsilateral DRG but was undetectable from $30 \mu \mathrm{g}$ of RNA from the contralateral DRG; therefore, the increase was at least 12-fold (data not shown). The absence of protected fragment in RNA from normal adult rat DRG and presence after nerve injury were consistent observations in three RNase protection assays with two separate RNA isolations from two separate group of rats.

In situ hybridization

By conventional in situ hybridization with oligonucleotide probes, IL-6 mRNA was detected in ipsilateral but not contralateral L5 DRG (Fig. 4A,B) $4 \mathrm{~d}$ after injury to the sciatic nerve. The hybridization signal was most prominent within a subpopulation (approximately one-half) of medium and large sized neurons (Fig. 4). Similar results and specificity were obtained by in situ hybridization with an antisense IL-6 RNA probe; no specific hybridization was detected with the sense probe (Fig. 4C,D).

The detection of IL- 6 mRNA was facilitated by PCR-enhancement of in situ hybridization (Fig. $4 E, F$ ). In control sections of DRG that were treated with RNase A before conventional or PCR-enhanced in situ hybridization, no hybridization signal was detected. Also, PCR-enhanced hybridization of sections treated with DNase but not reverse transcribed yielded no detectable hybridization signal. In scatter diagrams where labeling index was plotted as a measure of cell volume for 147 individual neurons in one DRG, a strong correlation between grain density for IL-6 mRNA and neuronal size was evident (Fig. 5). Thus, axotomy increases IL-6 mRNA predominately in mediumsized and large neurons (volume $>200,000 \mu \mathrm{m}^{3}$ ).

By in situ hybridization, it was neither demonstrated nor excluded that IL-6 mRNA is also present in non-neuronal cells.

\section{Bioactivity}

IL- 6 bioactivity was assayed by coculture of freeze-thawed DRG with the IL-6 dependent B9 cell line (Fig. 6). Incubation with ipsilateral DRG removed $4 \mathrm{~d}$ after nerve transection resulted in increased survival and/or proliferation of B9 cells comparable to that in the presence of $20 \mathrm{pm}$ IL-6 (10-27 pM, three assays). This bioactivity was completely inhibited by antiserum against rat IL-6 at a final dilution of 1:250. By this assay, contralateral DRG contained little or no IL-6. From these data, we estimate that approximately $4 \mathrm{fmol}$ of IL- 6 bioactivity are present in DRG after nerve injury.

\section{Discussion}

\section{IL-6 mRNA is induced in axotomized sensory neurons}

Transection of the sciatic nerve causes a rapid, substantial, and transient increase in the concentration of IL-6 mRNA in neurons of the corresponding lumbar DRG. Between 1 and $4 \mathrm{~d}$ after sciatic nerve transection, IL-6 mRNA was consistently detected in ipsilateral L4 and L5 DRG by multiple RT-PCR and RNase protection assays. With the same assays, IL-6 mRNA was consistently not detected in contralateral DRG or DRG from normal rats. The identity of the PCR product with IL- 6 mRNA was confirmed by DNA sequencing. After nerve injury, IL-6 mRNA was localized within a subpopulation of medium-sized to large neurons by three different techniques of in situ hybridization: no IL-6 mRNA was detected in neurons associated with uninjured sciatic nerves. The observations are consistent with previous evidence that IL-6 mRNA is induced within the facial motor nucleus after nerve injury although cellular localization was not 

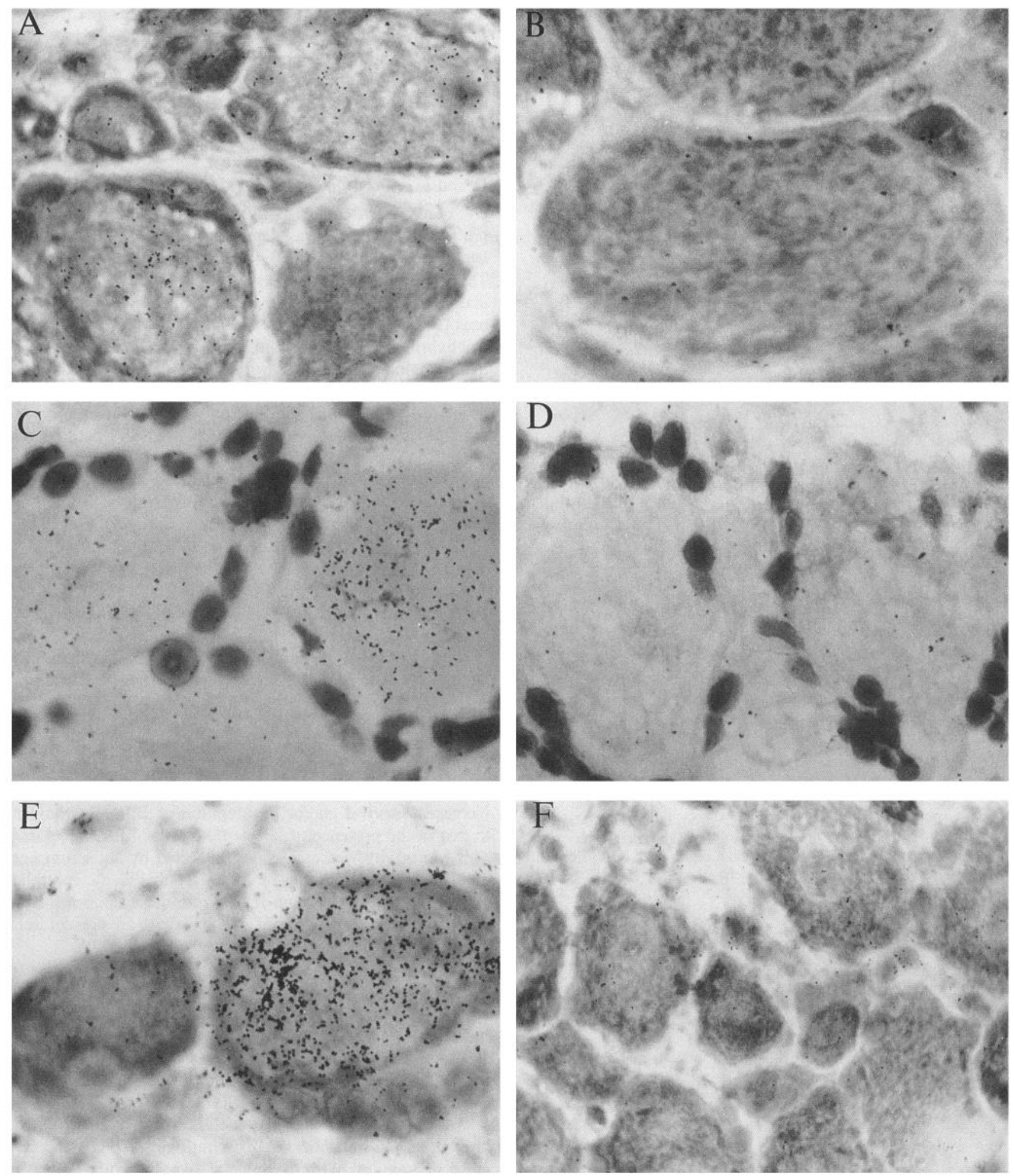

Figure 4. $\quad A$ and $B$, Conventional in situ hybridization with ${ }^{35}$ S-labeled IL-6 oligonucleotides of sections from ipsilateral $(A)$ and contralateral $(B)$ L5 DRG demonstrating labeling in two of four neurons from ipsilateral DRG but none from contralateral DRG. $C$ and $D$, In situ hybridization of ipsilateral DRG with ${ }^{35}$ S-labeled riboprobes of antisense $(C)$ and sense $(D)$ orientation demonstrating one heavily labeled neuron. $E$, PCR-enhanced in situ hybridization of ipsilateral DRG demonstrating strong labeling in a large neuron but background labeling only in an adjacent small neuron. $F$, Labeling is not above background in the contralateral DRG. Magnification: $A$ and $E, 850 \times ; B, 1100 \times ; C, 800 \times ; D, 900 \times ; F, 700 \times$. 


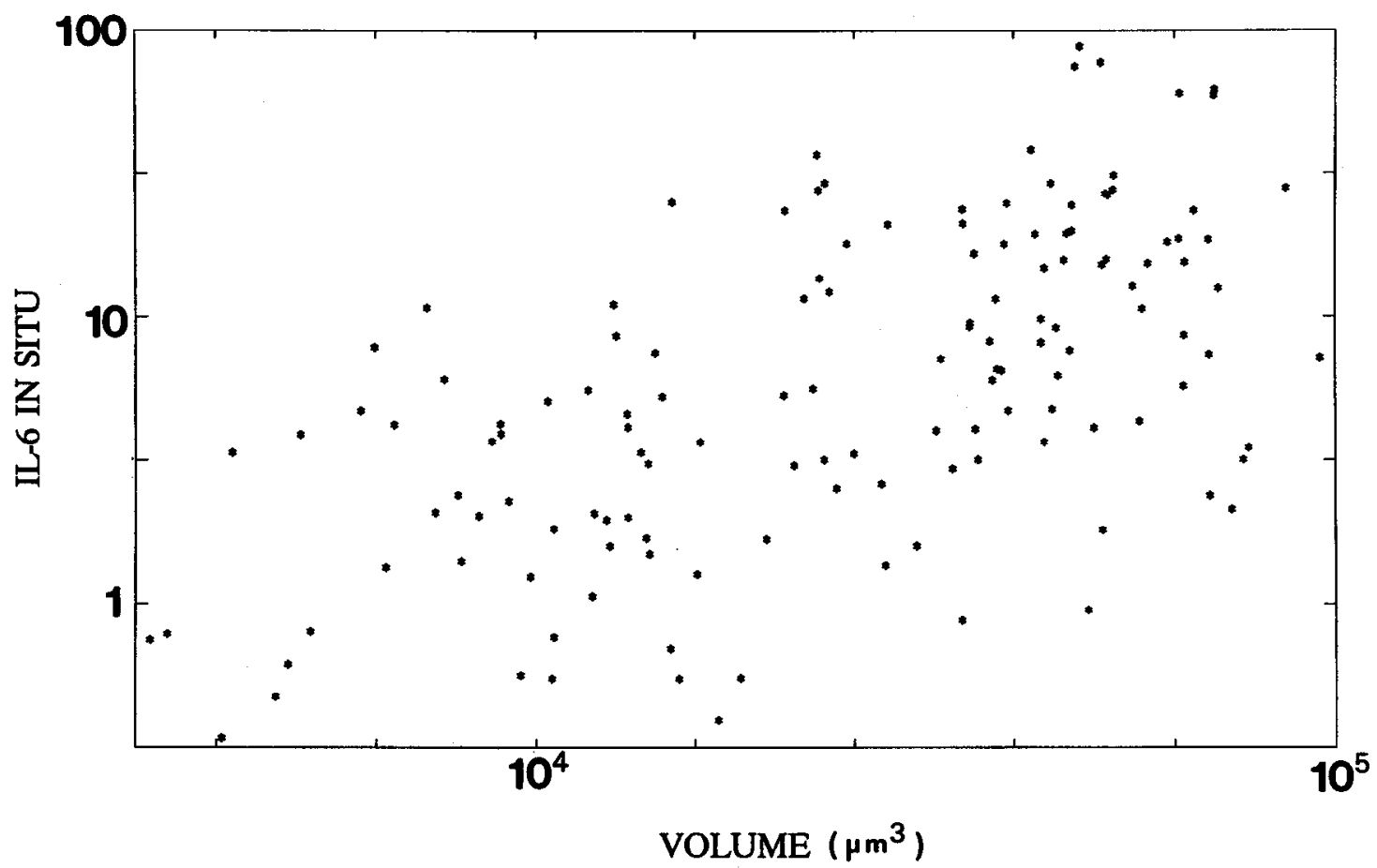

Figure 5. Labeling indices (ratio of neuronal labeling density to background labeling density) are plotted (log-log) against cell volume for 147 neurons in a single section from a DRG removed $4 \mathrm{~d}$ after nerve transection and processed for II -6 in situ hybridization. Volumes are calculated from diameters with the assumption that neurons are spherical. IL-6 labeling and cell volume are strongly correlated (Pearson coefficient $0.63, p$ $<0.001)$.

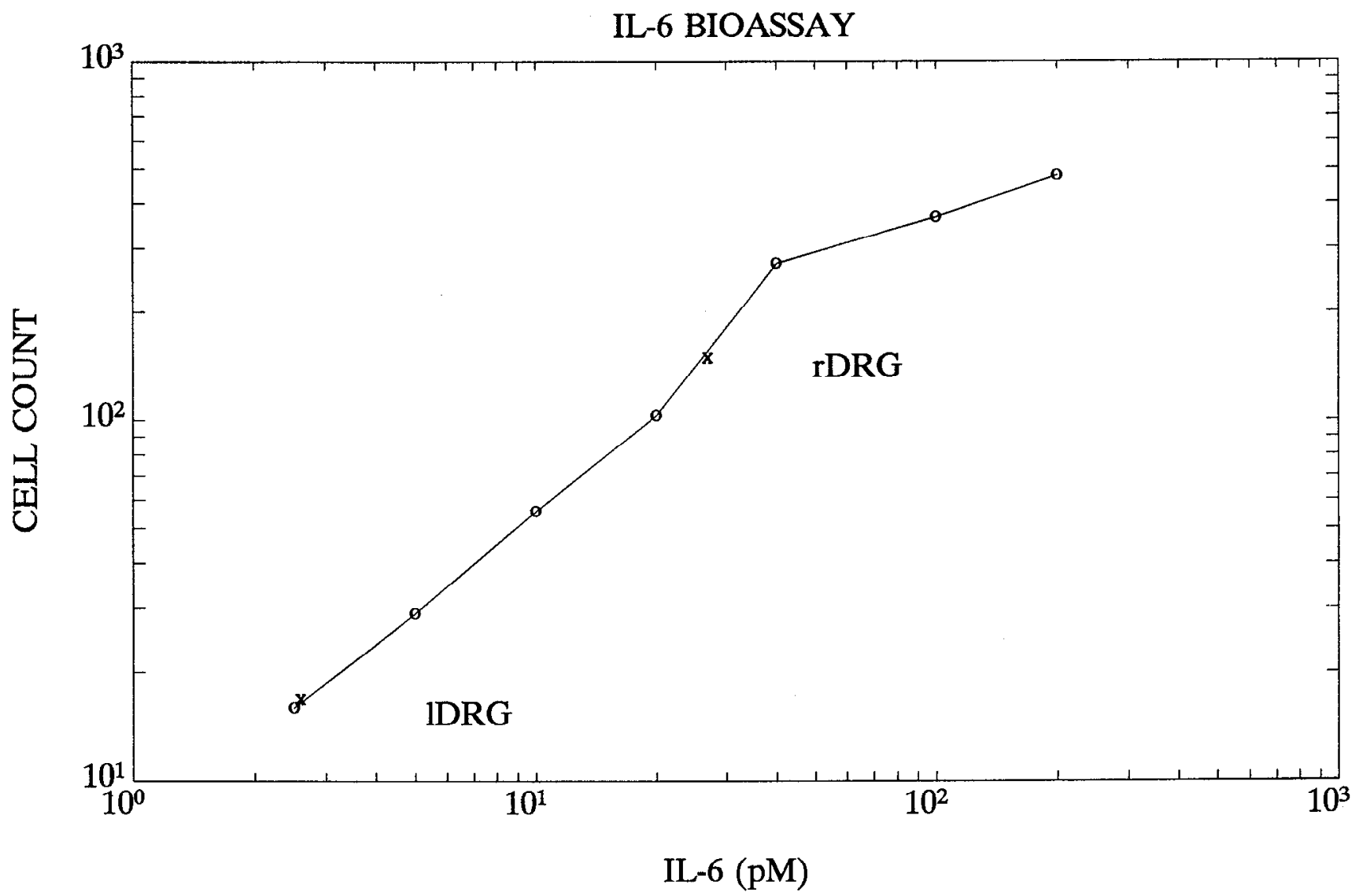

Figure 6. Representative B9 cell assay. Number of surviving cells per high power field is plotted against concentration of IL-6. In this assay, the effect of adding a freeze-killed ipsilateral DRG ( $r D R G)$ is comparable to the effect of 27 pM IL-6. A contralateral DRG (lDRG) yields a much smaller response. 
provided in the latter report (Kiefer et al., 1993). The induction of IL-6 mRNA in injured neurons, representing either increased transcription or increased stability of mRNA, is associated with an increase of IL- 6 bioactivity in the DRG.

The appearance of two other cytokines has been described in sensory neurons after axonal injury. TGF- $\beta$ (transforming growth factor) bioreactivity is released by sensory neurons in culture (Rogsiter et al., 1993). A molecule larger than interferon- $\gamma$ but with similar immunoreactivity and biological properties also appears in sensory neurons after nerve injury (Olsson et al., 1994).

The virtual absence of IL- 6 mRNA in DRG at 8 and $16 \mathrm{~d}$ after nerve injury indicates that the many macrophages in the ganglion (Lu and Richardson, 1993) are not then synthesizing IL-6. However, it remains possible that macrophages or other non-neuronal cells release IL-6 in the first few days after injury. Because of technical difficulties in detecting small amounts of mRNA in small cells, the negative results with in situ hybridization do not exclude an additional source of IL-6 mRNA in addition to neurons.

\section{Aetiology of IL-6 induction}

The early induction of IL- 6 within $1 \mathrm{~d}$ of axotomy could reflect a direct intraneuronal mechanism of induction initiated by interruption of retrograde axonal transport or an indirect mechanism involving perineuronal cells in the DRG. In other neurons, expression of neurotrophin genes is strongly influenced by increased electrical activity and glutamate receptors (Gall and Isackson, 1989; Zafra et al., 1991) but these stimuli are unlikely to be of major importance in axotomized sensory neurons. The brevity of interleukin- 6 induction in comparison with more prolonged inductions of GAP-43 (Woolf et al., 1990), c-jun (Jenkins and Hunt, 1991), and some peptides (Verge et al., 1995) is further evidence that signals to axotomized neurons are multiple (Moix et al., 1991).

In monocytes and monocyte-derived cell lines, transcription of the IL- 6 gene is activated by synergistic actions of two transcription factors NF- $\mathrm{BB}$ and c/EBP $\beta$ (also known as NF-IL-6, IL-6DBP, or LAP) acting on consensus response elements in the $5^{\prime}$ flanking sequence of the IL-6 gene (Libermann and Baltimore, 1990; Matsusaka et al., 1993; Stein et al., 1993). The translocation of NF-kB from cytoplasm to nucleus is regulated by the dissociation of $N \Gamma-\kappa \mathrm{B}$ from a family of $I \kappa \mathrm{B}$ proteins (Baeuerle and Baltimore, 1988; Ghosh and Baltimore, 1990; Davis et al., 1991; Inoue et al., 1992; I ink et al., 1992). NF-KB is constitutively expressed in neurons (Kaltschmidt et al., 1994) where it presumably contributes to the regulation of IL- 6 synthesis.

The restriction of IL-6 mRNA to a subpopulation of sensory neurons suggests some cell-specific gene regulation similar to that which restricts the distribution of neurofilament and neurotrophin receptors among sensory neurons (Verge et al., 1990; $\mathrm{Mu}$ et al., 1993). The subpopulation of medium and large sensory neurons containing IL-6 mRNA has not been characterized yet but could include neurons containing calbindin, trkB, trkC, or neuropeptide Y (Mu et al., 1993; Ernfors et al., 1994a,b; Verge et al., 1995).

\section{Possible functions of neuronal IL-6}

IL-6 synthesized by neurons could conceivably act on neurons and/or non-neuronal cells. The possibility that neuronal IL-6 has autocrine actions is suggested by the autocrine actions of IL- 6 in other cell types (Kawano et al., 1988; Tosato et al., 1990; Rieckmann et al., 1991) and the autocrine actions of BDNF on cortical neurons (Ghosh et al., 1994). Possible autocrine actions of IL- 6 in injured sensory ncurons might include changes in the synthesis of peptides, growth-associated molecules, or apoptosis-related molecules. IL- 6 from neurons might possibly influence the synthesis of trophic molecules or glial fibrillary acidic protein (Woodham et al., 1989) by satellite glial cells just as IL-1 and TNF- $\alpha$ stimulate the synthesis of NGF and LIF by nonneuronal cells in the CNS and PNS (Lindholm et al., 1987; Yoshida and Gage, 1992; Shadiack et al., 1994). IL-6 synthesized in sensory neurons presumably is transported in both central and peripheral axons and therefore in position to act on Schwann cells in the nerve and astrocytes or neurons in the spinal cord. The chronologies of IL-6 induction and macrophage hyperplasia are consistent with the hypothesis that IL-6 influences monocyte reactions in the DRG or spinal cord (Eriksson et al., 1993).

In DRG, as in other tissues, higher concentrations of IL-6 mRN $\Lambda$ have been detected during development than in mature animals. IL-6 is likely to have similar functions in developing or injured neurons perhaps related to growth of their axons.

\section{$I L-1 \beta$ and $T N F-\alpha$}

In comparison with IL-6, TNF- $\alpha$ and IL- $1 \beta$ mRNAs are induced with slower onset and longer duration, probably by different mechanisms. In DRG, the interval between nerve injury and appearance of IL- 1 mRNA is also longer than in sympathetic ganglia (Bai et al., 1994). The time course of appearance of IL$1 \beta$ and TNF- $\alpha$ mRNAs is consistent with the hypothesis that they are synthesized in macrophages accumulating in the DRG after nerve injury. However, the possibility that TNF- $\alpha$ and IL$1 \beta$ mRNAs arise from neurons or satellite glial cells has not been excluded.

\section{References}

Aarden LA, De Groot ER, Schaap OL, Lansdorp PM (1987) Production of hybridoma growth factor by human monocytes. Eur J Im munol 17:1411-1416.

Aloisi F, Rosa S, Testa U, Bonsi P, Russo G, Peschle C, Levi G (1994) Regulation of leukemia inhibitory factor syntliesis in cultured human astrocytes. J Immunol 152:5022-5031.

Baeuerle PA, Baltimore D (1988) IKB: a specific inhibitor of the NF$\mathrm{kB}$ transcription factor. Science 242:540-546.

Bai Y, Carlson CD, Ding M, Jonakait GM, Hart RP (1994) mRNA encoding IL-1 $\beta$, IL- 1 receptor, and IL-1 receptor antagonist are induced following sympathetic axotomy. Soc Neurosci Abstr 20:295.

Bandtlow CE, Meyer M, Lindholm D, Spranger M, Heumann R, Thoenen H (1990) Regional and cellular codistribution of interleukin lbeta and nerve growth factor mRNA in the adult rat brain: possible relationship to the regulation of nerve growth factor synthesis. J Cell Biol 111:1701 1711.

Bazan F (1991) Neuropoietic cytokines in the hematopoietic fold. Neuron 7:197-208

Beuscher HU, Rausch U-P, Oterness IG, Röllinghofr M. Transition from interleukin $1 \beta$ to IL- $1 \alpha$ during maturation of inflammatory macrophages in vivo. J Exp Med 175:1793-1797.

Campbell IL, Abraham CR, Masliah E, Kemper P, Inglis JD, Oldstone MBA, Mucke L (1993) Neurologic disease induced in transgenic mice by cerebral overexpression of interleukin 6. Proc Natl Acad Sci USA 90:10061-10065.

Chomczynski P, Sacchi N (1987) Single-step method of RNA isolation by acid guanidinium thiocyanate-phenol-chloroform extraction. Anal Biochem 162:156-159.

Davis N, Ghosh S, Simmons DL, Tempst P, Liou H-C, Baltimore D, Bose HR Jr (1991) Rel-associated pp40: an inhibitor of the Rel family of transcription factors. Science 253:1268-1271. 
Davis S, Yancopoulos GD (1993) The molecular biology of the CNTF receptor. Curr Opin Neurobiol 3:20-24.

Elde R, Cao Y, Cintra A, Brelje TC, Pelto-Huikko M, Junttila T, Fuxe K, Pettersson RF, Hokfelt T (1991) Prominent expression of acidic fibroblast growth factor in motor and sensory neurons. Neuron 7:349-364.

Eriksson NP, Persson JKE, Svensson M, Arvidsson J, Molander, Aldskogius $H$ (1993) A quantitative analysis of the microglial cell reaction in primary sensory projection territories following peripheral nerve injury in the adult rat. Exp Brain Res 96:19-27.

Ernfors P, Wetmore C, Olson L, Persson H (1990) Identification of cells in rat brain and peripheral tissues expressing mRNA for members of the nerve growth factor family. Neuron 5:511-526.

Ernfors P, Lee K-F, Jaenisch R (1994a) Mice lacking brain-derived neurotrophic factor develop with sensory deficits. Nature 368:147150.

Ernfors P, Lee K-F, Kucera J, Jaenisch R (1994b) Lack of neurotrophin-3 leads to deficiencies in the peripheral nervous system and loss of limb proprioceptive afferents. Cell 77:503-512.

Freidin M, Bennet MVL, Kessler JA (1992) Cultured sympathetic neurons synthesize and release the cytokine interleukin $1 \beta$. Proc Natl Acad Sci USA 89:10440-10443.

Gall CM, Isackson PJ (1989) Limbic seizures increase neuronal production of messenger RNA for nerve growth factor. Science 245:758761.

Gauldie J, Richards C, Harnish D, Lansdorp P, Baumann H (1987) Interferon beta $/ \mathrm{B}$-cell stimulating factor type 2 shares identity with monocyte-derived hepatocyte-stimulating factor and regulates the acute phase response in liver cells. Proc Natl Acad Sci USA 84:72517259.

Ghosh A, Carnahan J, Greenberg ME (1994) Requirement for BDNF in activity-dependent survival of cortical neurons. Science 263:16181623 .

Ghosh S, Baltimore D (1990) Activation in vitro of NF-kB by phosphorylation of its inhibitor IкB. Nature 344:678-682.

Goodman MN (1994) Interleukin-6 induces skeletal muscle breakdown in rats. Proc Soc Exp Biol Med 205:182-185.

Hama T, Kushima Y, Miyamoto M, Kubota M, Takei N, Hatanaka H (1991) Interleukin-6 improves the survival of mesencephalic catecholamines and septal cholinergic neurons from postnatal cholinergic neurons from postnatal, two-week-old rats in cultures. Neuroscience 40:445-452.

Hariri RJ, Chang VA, Barie PS, Wang RS, Sharif SF, Ghajar JBG (1994) Traumatic injury induces interleukin- 6 production by human astrocytes. Brain Res 636:139-142.

Inoue J-I, Kerr LD, Rashid D, Davis N, Bose HR Jr, Verma IM (1992) Direct association of $p p 40 / \mathrm{kB} \beta$ with rel/NF-kB transcription factors: role of ankyrin repeats in the inhibition of DNA binding activity. Proc Natl Acad Sci USA 89:4333-4337.

Ip NY, Nye SH, Boulton TG, Davis S, Taga T, Li Y, Birren S, Yasukawa K, Kishimoto T, Anderson DJ, Stahl N, Yancopoulos GD (1992) CNTF and LIF act on neuronal cells via shared signaling pathways that involve the IL-6 signal transducing receptor component gp130. Cell 69:1121-1132.

Jakubowski M, Roberts JL (1992) Multiplex solution hybridizationribonuclease protection assay for quantification of different ribonucleic acid transcripts from snap-frozen neuroendocrine tissues of individual animals. J Neuroendocrinol 4:79-89.

Jenkins R, Hunt SP (1991) Long-term increase in the levels of c-jun mRNA and Jun protein-like immunoreactivity in motor and sensory neurons following axon damage. Neurosci Lett 129:107-110.

Johnston RB Jr (1988) Monocytes and macrophages. N Engl J Med 318:747-752.

Kaltschmidt C, Kaldschmidt B, Neumann H, Wekerle H, Bauerle PA (1994) Constitutive NF-kB activity in neurons. Mol Cell Biol 14: 3981-3992

Kawano M, Hirano T, Matsuda T, Taga T, Horii Y, Iwato K, Asaoku H, Tang B, Tanabe O, Tanaka H, Kuramoto A, Kishimoto T (1988) Autocrine generation and requirement of BSF-2/IL-6 for human multiple myelomas. Nature 332:83-85.

Kiefer R, Lindholm D, Kreutzberg GW (1993) Interleukin-6 and transforming growth factor-beta $1 \mathrm{mRNAs}$ are induced in rat facial nucleus following motoneuron axotomy. Eur J Neurosci 5:775-781.

Kishimoto T, Akira S, Taga T (1992) Interleukin-6 and its receptor: a paradigm for cytokines. Science 258:593-597.
Kopf M, Baumann H, Freer G, Freudenberg M, Lamers M, Kishimoto T, Zinkernagel R, Bluethmann H, Kohler G (1994) Impaired immune and acute phase responses in interleukin-6 deficient mice. Nature 368 : $339-342$

Lee FD (1992) The role of interleukin-6 in development. Dev Biol 151:331-338.

Libermann TA, Baltimore D (1990) Activation of interleukin-6 gene expression through the $\mathrm{NF}_{-} \mathrm{KB}$ transcription factor. Mol Cell Biol 10: $2327-2334$.

Lindholm D, Heumann R, Meyer M, Thoenen H (1987) Interleukin-1 regulates synthesis of nerve growth factor in non-neuronal cells of rat sciatic nerve. Nature 330:658-659.

Link E, Kerr LD, Schreck R, Zabel U, Verma I, Baeuerle PA (1992) Purified IKB- $\beta$ is inactivated upon dephosphorylation. J Biol Chem 267:239-246.

Lisak RP, Bealmear B (1994) Antibodies to interleukin-6 inhibit Schwann cell proliferation by unfractionated cytokines. J Neuroimmunol 50:127-134.

Lotz M, Guerne P-A (1991) Interleukin-6 induces the synthesis of tissue inhibitor of metalloproteinases-1/erythroid potentiating activity. $\mathbf{J}$ Biol Chem 266:2017-2020.

Lu X, Richardson PM (1991) Inflammation near the nerve cell body enhances axonal regeneration. J Neurosci 11:972-978.

Lu X, Richardson PM (1993) Responses of macrophages in rat dorsal root ganglia following peripheral nerve injury. J Neurocytol 22:334 341 .

Lu X, Richardson PM (1995) Changes in neuronal mRNAs induced by a local inflammatory reaction. $J$ Neurosci Res, in press.

Marchionni MA, Goodearl ADJ, Chen MS, Bermingham-McDonogh O, Kirk C, Hendricks M, Danehy F, Misumi D, Sudhalter J, Gwynn D (1993) Glial growth factors are alternatively spliced erbB2 ligands expressed in the nervous system. Nature 362:312-318.

Matsusaka T, Fujikawa K, Nishio Y, Mukaida N, Matsushima K, Kishimoto T, Akira S (1993) Transcription factors NF-IL6 and NF-кB synergistically activate transcription of the inflammatory cytokines, interleukin 6 and interleukin 8. Proc Natl Acad Sci USA 90:1019310197.

Moix LJ, Gresson DM, Armstrong DM, Wiley RG (1991) Separate signals mediate hypoglossal motor neuron response to axonal injury. Brain Res 564:176-180.

Mu X, Silos-Santiago I, Carroll SL, Snider WD (1993) Neurotrophin receptor genes are expressed in distinct patterns in developing dorsal root ganglia. J Neurosei 13:4029-4041.

Nishida T, Hirato T, Nishino N, et al. (1988) Cloning of the cDNAs for rat interleukin- $1 \alpha$ and $\beta$. In: Monokines and other non-lymphocytic cytokines, pp 73-78. New York: Liss.

Norris JG, Beneviste EN (1993) Interleukin-6 production by astrocytes: induction by the neurotransmitter norepinephrine. J Neuroimmunol $45: 137-146$

Northemann W, Braciak TA, Hattori M, Lee F, Fey GH (1989) Structure of the rat interleukin 6 gene and its expression in macrophagederived cells. J Biol Chem 264:16072-16082.

Olsson T, Kelic S, Edlund C, Bakhiet M, Höjeberg B, van der Meide P, Ljundahl Å, Kristersson K (1994) Neuronal interf 'ron- $\gamma$ immunoreactive molecule: bioactivities and purification. Eur J Immunol $24: 308-314$

Patterson PH (1992) The emerging neuropoietic cytokine family: first CDF/LIF, CNTF and IL-6; nexı ONC, MGF, GCSF. Curr Opin Neurobiol 2:94-97.

Poli V, Balena R, Fattori E, Markatos A, Yamamoto M, Tanaka H, Ciliberto G, Rodan GA, Costantini F (1994) Interleukin-6 deficient mice are protected from bone loss by estrogen depletion. EMBO J 13:1189-1196

Rieckmann P, D'Alessandro F, Nordan RP, Fauci AS, Kehrl JH (1991) IL- 6 and tumor necrosis factor- $\alpha$ : autocrine and paracrine cytokines involved in B cell function. J Immunol 146:3462-3468.

Rogister B, Delrée P, Leprince P, Martin D, Sadzot C, Malgrange B, Munaut C, Rigo JM, Lefebvre PP, Octave J-N, Schoenen J, Moonen $G$ (1993) Transforming growth factor $\beta$ as a neuronoglial signal during peripheral nervous system response to injury. J Neurosci Res 34:32-43.

Sambrook J, Fritsch EF, Maniatis T (1989) Molecular cloning: a laboratory manual, $2 \mathrm{~d}$ ed. Cold Spring Harbor, NY: Cold Spring Harbor Laboratory.

Sasahara M, Fries JWU, Raines EW, Gown AM, Wedstrum LE, Frosch 
MP, Bonthron DT, Ross R, Collins T (1991) PDGF B-chain in neurons of the central nervous system, posterior pituitary, and in a transgenic model. Cell 64:217-227.

Satoh T, Nakamura S, Taga T, Matsuda T, Hirano T, Kishimoto T, Kaziro $\mathrm{Y}$ (1988) Induction of neuronal differentiation in PC12 cells by B-cell stimulatory factor 2/interleukin 6. Mol Cell Biol 8:3546-3549.

Schöbitz B, de Kloet ER, Sutanto W, Holsboer F (1993) Cellular localization of interleukin 6 mRNA and interleukin 6 receptor mRNA in rat brain. Eur J Neurosci 5:1426-1435.

Seniuk N, Altares M, Dunn R, Richardson PM (1992) Decreased synthesis of ciliary neurotrophic factor in degenerating peripheral nerves. Brain Res 572:300-302.

Shadiack AM, Hart RP, Carlson CD, Jonakait GM (1993) Interleukin-1 induces substance $P$ in sympathetic ganglia through the induction of leukemia inhibitory factor (LIF). J Neurosci 13:2601-2609.

Shadiack AM, Carlson CD, Ding M, Hart RP, Jonakait GM (1994) Lipopolysaccharide induces substance $\mathrm{P}$ in sympathetic ganglia via interleukin production. J Neuroimmunol 49:51-58.

Shah NM, Marchionni MA, Isaacs I, Stroobant P, Anderson DJ (1994) Glial growth factor restricts mammalian neural crest stem cells to a glial fate. Cell 77:349-360.

Shirai T, Shimizu N, Horiguchi S, Ito H (1989) Cloning and expression in Escherichia coli of the gene for rat tumor necrosis factor. Agric Biol Chem 53:1733-1736.

Shohami E, Novikov M, Bass R, Yamin A, Gallily R (1991) Closed head injury triggers early production of $\mathrm{TNF} \alpha$ and IL- 6 by brain tissue. J Cereb Blood Flow Metab 14:615-619.

Stahl N, Boulton TG, Farruggella T, Ip NY, Davis S, Witthuhn BA, Quelle FW, Silvennoinen O, Barbieri G, Pellegrini S, Ihle JN, Yancopoulos GD (1994) Association and activation of Jak-Tyk kinases by CNTF-LIF-OSM-IL-6 beta receptor components. Science 263:9295.

Tosato G, Tanner J, Jones KD, Revel M, Pike SE (1990) Identification of interleukin- 6 as an autocrine growth factor for Epstein-Barr virusimmortalized B cells. J Virol 64:3033-3041.

Tso JY, Sun XH, Kao TH, Reece KS, Wu R (1985) Isolation and characterization of rat and human glyceraldehyde 3-phosphate dehydrogenase cDNAs: genomic complexity and molecular evolution of the gene. Nucleic Acids Res 13:2485 2502.

Verge VMK, Tetzlaff W, Bisby MA, Richardson PM (1990) Influence of nerve growth factor on neurofilament gene expression in mature primary sensory neurons. J Neurosci 10:2018-2025.

Verge VMK, Richardson PM, Wiesenfeld-Hallin Z, Hökfelt T (1995) Differential influence of nerve growth factor on neuropeptide expression in vivo-a novel role in peptide suppression in adult sensory neurons. J Neurosci, in press.

Woodham P, Anderson PN, Nadim W, Turmaine M (1989) Satellite cells surrounding axotomized rat dorsal root ganglion cells increase expression of a GFAP-like protein. Neurosci Lett 98:8-12.

Woodroofe MN, Sarna GS, Wadha M. Hayes GM, Loughlin AJ, Tinker A, Cuzner ML (1991) Detection of interleukin-1 and interleukin-6 in adult rat brain, following mechanical injury, by in vivo microdialysis: evidence of a role for microglia in cytokine production. J Neuroimmunol 33:227-236.

Woolf CJ, Reynolds ML, Molander C, O’Brien C, Lindsay RM, Benowitz LI (1990) The growth-associated protein GAP-43 appears in dorsal root ganglion cells and in the dorsal horn of the rat spinal cord following peripheral nerve injury. Neuroscience 34:465-478.

Yamada M, Hatanaka H (1994) Interleukin-6 protects cultured rat hippocampal neurons against glutamate-induced cell death. Brain Res 643:173-180.

Yan HQ, Banos MA, Herregodts P, Hooghe R, Hooghe-Pters EL (1992) Expression of interleukin $1 \beta$, IL- 6 and their respective receptors in normal rat brain and after injury. Eur J Immunol 22:2963-2971.

Yeh H-J, Ruit KG, Wang Y-W, Parks WC, Snider WD, Deuel TF (1991) PDGF A-chain gene is expressed by mammalian neurons during development and in maturity. Cell 64:209-216.

Yoshida K, Gage F (1992) Co-operative regulation of nerve growth factor synthesis and secretion in fibroblasts and astrocytes by fibroblast growth factor and other cytokines. Brain Res 569:14-25.

Zafra F, Lindholm D, Castrén E, Hartikka J, Thoenen H (1992) Regulation of brain-derived neurotrophic factor and nerve-growth factor mRNA in primary cultures of hippocampal neurons and astrocytes. 